\title{
Lean Methodology and Nursing
}

\author{
Gadea Company P* and Budía Alba A \\ Lithotripsy and Endourology Unit, La Fe University and Polytechnic Hospital, Valencia (Spain)
}

Submission: July 08, 2019; Published: July 17, 2019

*Corresponding author: Patricia Gadea Company, Lithotripsy and Endourology Unit, La Fe University and Polytechnic Hospital, Carrer L'alguer, 8. 46022 Valencia, Spain

\section{Opinion}

Lean methodologies have been applied in healthcare and have shown promising results in different Health Services. Some examples are United States organizations such as the Institute for Healthcare Improvement, and the United Kingdom such as the NHS Confederation and the Institution for Innovation and Improvement [1]. Lean methodology is derived from the Japanese manufacturing industry. The Japanese automobile manufacturer Toyota optimized their workflow and efficiency by developing principles of the Toyota Production System [2] Key principles include the elimination of unnecessary waste, minimizing delays, just in time delivery of products and services, worker empowerment, and continuous improvement [3]. Lean methodology involves principles, methods, and tools to understand and improve the performance of a system. An example of Lean, 5S (sort, straighten, scrub, standardize, sustain) can be useful in healthcare as a method for organizing and standardizing workspaces.

The main advantages of the application of Lean Healthcare methodology are the reduction of costs, optimization of resources, the improvement of the feedback, activity systematization for reduction of variability in clinical practice $[4,5]$. The methodology fosters engagement workers and leaders to identify waste in a process, minimizing it and being adaptable for eliminating waste or non-value activities. It allows to reduce loses, to develop standards implementing changes, to optimize workflow through strategic operational procedures and to assess the results of that change, reviewing next steps and repeating the process (Deming cycle).

In nursing, the application of Lean methodology allows to optimize the time in the specific tasks, to increase patient safety and to develop a similar care plan. The design of different processes gets the systematization of the activity and the possibility of controlling it with the use of indicators. The monitoring of the indicators lets us decide changes in the process and to maintain a continuous improvement. The use of safety indicators of the process allows us to improve the patient safety and even to implement specific tools like FMEA (Failure Modes and Effects Analysis) in the process. All this combined in a work system oriented to the patient in which the patient is the center of our activity.

The systematization of the activity in nursing practice has an added value: any new worker that is part of the team can learn the tasks and processes quickly. The systematization of the activity decreases clinical variability in clinical practice in nursing and allows a quick specialization of the nursing staff and a simple learning process. This is also favorable for the process of patient recovery and safety. One of the biggest drawbacks that we could find implementing Lean is that it requires the hospital and medical leadership to be all strong supporters of the methodology, to speak the same process improvement language and to be able to generate support and resources for forward movement. The support and acceptance of the workers will have an important role for the daily development of the nursing activities. For that, it is necessary to achieve a complete alignment between all the staff, including all professional categories. Knowing the reasons of using this methodology and the main objective of this way of working is an important step for reaching the alignment. The improvement of indicators, efficiency and care quality perception by patients increase the satisfaction of the staff as well, maintaining the intrinsic motivation over the time.

The implementation of Lean methodology in the nursing office in our department allowed us to increase the patient care time. Implementing Lean philosophy and methods improved the patient flow and quality of care decreasing waiting times. The assistance quality and patient satisfaction were increased applying this methodology. Therefore, the use of Lean methodology can be applied to improve efficiency in nursing assessment and healthcare as we have demonstrated, and it will be shown in future publications. One might say that working with Lean methodology brings the opportunity to understand beyond the clinical practice. The use of Lean methodology is something complex that requires time for its implementation. In my opinion, the optimization of resources, the improvement of effectiveness and economic outcomes would have a positive impact on the Health System and of course, on the society. As a nurse, I understood that sharing a work philosophy with the team makes us better and grow together for the patient. 


\section{References}

1. Honeycutt L, Keller S (2018) Effectiveness of the lean process compared to other quality improvement initiatives on length of stay and wait times in healthcare organizations: asystematic review protocol. JBI Database Syst Rev Implement Rep 16(1): 12-20.

2. Skeldon SC, Simmons A, Hersey K, Finelli A, Jewett MA, Zlotta AR, et al. (2014) Ambulatory and office Urology Outpatient Academic Urooncology Clinics. Urology 83(5): 992-998.
3. Bonome L, Costa M, Filho MG (2017) Lean healthcare: review, classification and analysis of literature. 27(10): 1-21.

4. Kim C, Spahlinger D, Kin J, Coffey R, Billi J (2009) Implementation of Lean Thinking: one health System's Journey. Koint Comm J Qual Patient Safety 35(8): 406-413.

5. Harper P, Klein J (2004) Using industrial processes to improve patient care. Br Med J 328: 162-164.

\section{Your next submission with Juniper Publishers will reach you the below assets}

- Quality Editorial service

- Swift Peer Review

- Reprints availability

- E-prints Service

- Manuscript Podcast for convenient understanding

- Global attainment for your research

- Manuscript accessibility in different formats

( Pdf, E-pub, Full Text, Audio)

- Unceasing customer service

Track the below URL for one-step submission https://juniperpublishers.com/online-submission.php 